\title{
Review for Performance Of Indian Nationalised Banks
}

\author{
Nampalli Srishylam ${ }^{a}$, Dr. Rajesh Sharma ${ }^{\text {b }}$ \\ a Research Scholar, Dept. of Management, \\ Sri Satya Sai University of Technology \& Medical Sciences, Sehore, Bhopal Indore Road, Madhya Pradesh, India \\ ${ }^{\mathbf{b}}$ Research Guide, Dept. of Management, \\ Sri Satya Sai University of Technology \& Medical Sciences, Sehore, Bhopal Indore Road, Madhya Pradesh, India
}

Article History: Received: 11 January 2021; Accepted: 27 February 2021; Published online: 5 April 2021

\begin{abstract}
The banking industry in India overall is making huge commitments to the improvement of the economy and assisting with accomplishing economical growth. The banks are helping the economy regarding successful capital arrangement, viable loaning, and adding to the improvement of the country, in this way banks should be all the more firmly watched. In India, banks are probably the best entertainer on the planet banking industry seeing colossal seriousness, growth, productivity, benefit, and adequacy, particularly lately. The principle objective of banks today is to guarantee solidness and ensure that they are inside sound and reasonable. Subsequently, it is imperative to quantify sufficiency across different banks in the country and distinguish the more fragile segments of the banking area, devise suitable systems and approaches to lift these areas, and in the end, establish a climate that leads banks to be sound and results in instability.
\end{abstract}

\section{Introduction}

The performance of the financial institutions is a significant worry for both, the controllers and the policymakers since it has a solid linkage with the performance of the economy. The financial area is sensibly all around created in India. Despite the fact that little in contrast with, say, the USA, it has a solid banking system, a bunch of huge and little stock and item trades, solid value culture, enormous number of common assets, advancement institutions like Industrial Development Bank of India, non-Banking account organizations, other particular financial institutions, other than a huge casual area. India, since the 1950s picked the blended economy model, with a solid accentuation on the public area.

The banking area contains three significant sections: Scheduled Commercial banks, State Cooperative Banks, and different banks like NABARD. The booked business banks incorporate every single significant bank and record for over $98 \%$ of the multitude of assets in the banking area. The Indian banking industry, which is a significant channel of subsidizing the profitable area, was generally in the private area until 1969 when all the significant Indian banks in the private area were nationalized. Another arrangement of banks was nationalized during the 1980s. A few private area banks and some unfamiliar banks worked however on a generally limited scale. By 1991, most banking assets were in the public area. Confronting a significant economic emergency, India began changing its economy in 1991, decreasing or killing controls on numerous areas, and permitting the private area to take an interest where it was before either denied or confined. The financial area, including the banking area, was likewise changed. The public authority additionally chose to smooth out the capital market, which was up to this point consumed by one significant stock trade. Major new stock trade and new administrative body were set up.

\section{Review of Literature}

MelakuAlemu et al (2017) have analysed the performance of private business banks utilizing CAMEL rating model in their investigation. Tests of 6 private banks were taken for their examination for a time of 10 years. The general performance of the banks was appraised utilizing clear factual apparatuses, and the effect of CAMEL factors were estimated utilizing the board relapse model. To decide the benefit sway, illustrative factors were utilized. The banks were recorded based on different illustrative and inferential examinations.

Pankil Solanki et al (2017), in their exploration paper, analyzed the benefit of a couple of chosen private area and PSBs' in India. The investigation included two significant components which affected the benefit assessment by utilizing factual apparatuses like mean, deviation from mean alongside ANOVA. Yearly investigation of Return on Capital Employed showed that private banks had outflanked public area banks. It got basic for the public banks to utilize their capital productively to accomplish better benefits and challenge the private area banks in India.

Ahmad Waleed et al (2015) looked at the performance of both Private and Public Banks of Pakistan in their investigation. Optional information had been utilized for the time of 2011-2014. Three classes of proportions were utilized for examining the performance of the banks. The discoveries of the investigation depended on the bank's size, liquidity and productivity proportions. Concerning the complete assets, private banks in Pakistan were bigger than the public banks. Private Banks drove the public banks based on Liquidity proportions, while the public banks did based on profit for assets proportion.

Ashish Gupta et al (2015), in their investigation article, surveyed the financial performance several PSBs for the time period 2009-2013. Extents that impacted the financial position were applied to quantum efficiency, 
legitimacy and liquidity of the select banks. The examination focused in on the instabilities of components related to banking. The examination showed that total banking similarity gathered slowly inside the hour of assessment.

AnsarulHaque (2014), analyzed and assessed the performance a couple of significant banks in India during the time frame 2009-2013 in their examination paper. The examination analyzed the financial situation of different unfamiliar booked business banks. He utilized different factors and ANOVA to consider the relationship of means in benefit among different banking layers. The investigation uncovered that there was relationship in the methods for the benefit between the unfamiliar banks based on Return on Assets and Net Interest Margin, however there was no relationship among the banks in regard of Return on Equity.

Hemal Pandya (2014), in his examination paper named, "Distinguishing Major Determinants of Profitability for chose Nationalized Banks in India," investigated the relationship among the financial proportions of select nationalized banks utilizing different factual devices and strategies. The benefit of nationalized banks were generally impacted by a general Business profitability factor. The critical determinants of benefit of the picked banks shifted among banks; nonetheless, the 5 preeminent affecting issues were known. It was unmistakably projected that benefit was reliably diminishing until the year 2007-2008; at the same time, consequently there was a little expansion in important proportions. Along these lines, benefit contained a shaky pattern over the chose extent of study with an ascent in next two-three years.

ManvinderTandon et al (2014), in their investigation, broke down five banks dependent on different benefit proportions for the time frame 2009-2014. They utilized proportions to quantify the benefit and the financial performance of the select banks.

Mustafa Hassan et al (2014), examined the financial performance of EBIF, Iraq. Financial proportion examination was utilized to quantify the bank's performance, and factual instruments were utilized to break down the factors under investigation. The examination uncovered a solid conduct of the bank. A couple of financial factors impacted the financial boundaries of the bank. The investigation prescribed to build the quantity of bank offices, account agribusiness and SSI ventures and use data innovation and support in Capital market.

Ayyappan et al (2013), in their article, estimated 26 financial factors with suitable measurable devices. In their examination, eight select public area banks were assessed by thinking about the productivity factors. The measurable device Path Analysis decided the firm and restricting contributions of the chose factors under the investigation term. The financiers needed to consider the realities that affected contrarily, which was useful to improve the benefit in this general rivalry.

Jaimin Patel and Kishore Bhanushali, in their article named, "Near Study of Profitability of Nationalized Banks and PSBs," researched the efficiency of three select Indian Banks for the time frame 2010-2015. A careful assessment of the productivity of private and nationalized banks demonstrated positive outcomes. Banking area faces an expanded rivalry, which makes benefit making a requesting task for Indian banks. They needed to buckle down for their improvement and ascend in productivity. The costs of the banks ought to be monitored and just a proficient utilization of resources would help them in a more noteworthy manner.

Dr. Ali Mohmoud (2014) The examination is about banks and other financial establishments are significant piece of the economy in a specific nation as well as for everywhere on the world and the principle standards for assessment is benefit. The creator has chosen SBI as Indian Bank and Cairo Amman Bank (CAB) as Jordian bank for examination. Both the wellsprings of information assortment as essential information and optional information from reports magazines and web is gathered. The time of study is 2006-07 to 2010-11. The bookkeeping year for SBI is April to March and for CAB its from January to December. The proportions is the applied investigation apparatus for the examination. Proportions like Gross Profit proportion, Net Profit proportion, Operating Profit proportion, Operating proportion and so on are utilized. According to Gross Profit proportion $\mathrm{CAB}$ is superior to SBI. Again if there should arise an occurrence of Net Profit proportion CAB is superior to SBI. For Operating Profit likewise CAB is prevalent. If there should arise an occurrence of Return on value investors store the performance of both the banks is similarly acceptable.

B. G SATYA PRASAD (2012) it very well may be summarize that unfamiliar banks worked much better, private area banks on second number and public area are yet to go for headway. Yet, while contrasting public and private area banks public area banks are a lot of stable in the performance when contrasted with private area banks. Unfamiliar banks are much ahead in the two factors like worker's effectiveness just as financial performance.

AbdallahAlrabei (2013) The time of study is 2007-08 to 2011-12. The primary instrument of investigation embraced is proportion examination. The creator has chosen the principle and significant proportions for investigation which appropriately affects the examination. The profile of both the banks is concentrated appropriately including its branches and auxiliaries. The limits unmistakably referenced that the investigation is just based on auxiliary information and which must be windowdressed.

CheenuGoel (2013) The paper is around three significant private area banks for example ICICI Bank, HDFC Bank and Axis Bank. For examination the public area banks are SBI, Punjab National Bank and Bank of Baroda. The time span covered is 2009-2011.Due to client necessity or interest, rivalry of the market and changes in the 
banking area proficiency and productivity are of most extreme significance. The measurement of yield in such a way is truly troublesome as it is immaterial. The primary part considered is size of bank assets. The fundamental apparatus utilized for the examination are various proportions like Return on Assets, Return on Equity, Net Interest Margin. Understanding is for the most part based on Demand Deposit Ratio for example relationship of Demand Deposit to Total Deposits. The proportion utilized is Saving Deposit Ratio for example connection of Saving store to Total stores. Next is Net Interest Margin for example (Interest got and Interest paid) distinction complete assets. Next is Credit Deposit Ratio for example extent of credits produced by banks from stores got. The proportion utilized is Debt Equity Ratio which shows money of the association via debt and value.

Ms.PriyankaTondon (November 2011) Return on resource shows productivity of business utilizing its own assets to create the pay. Profit for value shows how much the profit for investors store is. Capital Adequacy Ratio is to choose bank's ability to pay time just as different liabilities. Working Margin Ratio is about the all out pay to working pay.

ChitwanBhutaniRekhi (July 2013) Changing innovation and markets are the essential powers driving associations to change inside. Creator has made four pieces of nationalized banks: corporate office, zonal office, divisional office and branches. Here in SWOT investigation openings and Threats are External interface and Strengths and shortcoming are Internal interface. The PSB ${ }^{\text {ee }}$ s are clubbed into specific classifications like Strong and fruitful banks, bank and resuscitating banks. In this examination creator unequivocally accept that various sub-systems are similarly significant. With that a solid chief with mission and vision is a restrictive variable. Numerous fixings are given for systematic upgrade.

P.S.R. Prasad (2015) Author sets up six standards to adapt up to changing outside climate. In real life plan they propose that the time is proper to define a few teams with individuals drawn from cross utilitarian and hierarchic, in this way guaranteeing aggregate responsibility. It will likewise offer opportunity to make eventual fate of center and junior workplaces in nationalized banks. Accomplishment in the commercial center won't be made accessible on a platter. It should be procured. Initiative will be the main point of interest and this is actually in bountiful stock.

A.D. Bhorkar (2015), The proportions to be utilized in the way for example legitimate with insightful understanding. It may not offer you responses however it can bring up the issues. Edges are one of the significant parts of examination. Just increment is edge in huge figures isn't adequate. Why it is so is vital. Low edges are few out of every odd time terrible. Edges assist us with discovering cast design, benefit and friends' capacity to force the cast on the buyers. Benefit proportions are contrasting the organization and the other industry or it tends to be made with its own earlier year's performance. Pattern investigation in proportions can be the fascinating piece of the proportion examination. Proportions are valuable to think about the liquidity of the organization. Each individual will initially assess the organization with this, regardless of whether the organization can pay its current commitments and have adequate assets to maintain a business effectively. .The proportion examination for banks is fundamentally for contributors, investors and loan bosses. On the off chance that the return is low, at that point the danger is high. The influencing factors are working outcomes, nature of assets, dependability of obligation and so forth So just proportions of productivity, liquidity, assets quality, and capital and ampleness are significant.

A.S.Puri (2013) To remain in market with non banking foundations the banks need to concentrate needs of clients, administrations given by them and clients input, likewise the bank needs to make 48 strides: 1) current innovation 2) data, correspondence and coordinations 3) staff preparing 4) client instruction Deployment of assets and nature of advances have their impact in deciding the likelihood. So the bank needs to care for their economic feasibility of advances.

Chaudhary K et al(2011), "Performance of Indian Public Sector Banks and Private Sector Banks: A Comparative report ", in his examination to look at public and private area banks performance and assess patterns in NPA Level and recommends NPA Management. Study dependent on auxiliary information and to examination factual devices for projection of extortion. Study periods from 2009-2010.Finding investigation need for improve effective administration data system in banks and legitimate choice of task to dissecting the financial assertions. Guruswamy D. (2012), "Investigation of Profitability Performance of SBI and its Associates", its goals discover benefit and performance of SBI and related Bank. Exploration dependent on essential dependent on auxiliary information utilized factual apparatuses like mean, standard deviation, difference and accumulate yearly growth rate and Anova through SPSS programming. Periods 1996 to 2007. Discoveries related bank acquired most noteworthy benefit connection to Net worth contrasted with SBI.

Malviya M., (2012), "An Analysis on the Profitability, Risk and Growth Indicators of Public and Private Sector Banks", in his plan to examine the benefit, danger and growth of public area banks for the financial year 20102011. Information gathered from rundown of pay articulations and Balance Sheet of six fundamental Banks. Strategy used to proportion examination and look at public and private area banks benefit. Finding in examination work for public area banks more elevated level of productivity and private area banks created more 
income for each put resources into assets. Public area banks proficient account growth methodologies and private area banks indispensable parts of growth methodology.

Gauba R., (2012), "The Indian Banking Industry: Evolution, Transformation and the Road Ahead", His target to consider the major groundbreaking point in banking industry and current Level of banking in India. Study dependent on auxiliary information and gathered from banking reports and RBI Reports. Times of study taken from 2009-10 to 2010-11 and instruments used to consider pay and use patterns and measure performance. Generally end Indian banking industry face challenge financial consideration, the board of resource quality and so on.

Zafar T.S.M et al (2012), "A Study of Ten Indian Commercial Bank's Financial Performance utilizing Camels Methodology", in his investigation to examination quantitative components include in assessing performance of Indian business banks and checks the ampleness of Camel module suggestion for development of the banks performance. Study depended on optional information and gathered from yearly reports of banks from 2005-06 to 2009-10. Instruments used to investigation Camel method like: Capital ampleness proportion, resource quality, the executives effectiveness and so forth Investigation discovering performance during year better and all the banks touchy and liable for client need.

Meghani et.al (2015)1 study aimed to analyse the financial position and performance of theBankofBarodaandPunjabNationalBankinIndiabasedontheirfinancial characteristics with the assessment of CAMEL Model. The study findings revealed that the two banks had succeeded in maintaining CRAR (Capital Reserve Adequacy Ratio) at a higher level than the prescribed level, 10per cent. The study also observed that Bank of Baroda had maintained highest duringthestudy period, which was considered as very good sign for the banks to survive and to expand in future. The study also found that out Meghani et.al (2015)1 study aimed to analyse the financial position and performance theBankofBarodaandPunjabNationalBankinIndiabasedontheirfinancial characteristics with the assessment of

CAMEL Model. The study findings revealed that the two banks had succeeded in maintaining CRAR (Capital Reserve Adequacy Ratio) at a higher level than the prescribed level, 10per cent. The study also observed that Bank of Baroda had maintained highest duringthestudy period, which was considered as very good sign for the banks to survive and to expand in future. The study also found that out Meghani et.al (2015)1 study aimed to analyse the financial position and performance of theBankofBarodaandPunjabNationalBankinIndiabasedontheirfinancial characteristics with the assessment of CAMEL Model. The study findings revealed that the two banks had succeeded in maintaining CRAR (Capital Reserve Adequacy Ratio) at a higher level than the prescribed level, 10per cent. The study also observed that Bank of Baroda had maintained highest duringthestudy period, which was considered as very good sign for the banks to survive and to expand in future. The study also found that out Meghani et.al (2015) study meant to analyse the financial position and performance of the Bank of Baroda and Punjab National Bank in India dependent on their financial qualities with the appraisal of CAMEL Model. The investigation discoveries uncovered that the two banks had prevailing with regards to looking after CRAR (Capital Reserve Adequacy Ratio) at a more elevated level than the endorsed level, 10per penny. The examination likewise saw that Bank of Baroda had kept up most elevated during the investigation time frame, which was considered as generally excellent sign for the banks to endure and to extend in future. The examination additionally found that out of 14 proportions utilized in the CAMEL model the normal figures of Bank of Baroda had recorded proficiency for six proportions followed by Punjab National Bank for five proportions. The discoveries of the investigation inferred that Bank of Baroda was the best performing bank under the public area class.

\section{Conclusion}

Around 40per cent of the gross national savings are deployed in bank deposits, and theroleofthe banking system as asourceof credit is crucial. However, with the deregulationo finterest rates and the rise of capital markets, the exposure of the banks' market risk assets have increased. The absenceofadequatecapital toabsorbmarket risk ismanifestedthroughprice volatility in mark to market assets and thus can further accentuate the problems of the banking sector. The recent global financial crisis found this cause in the sustained under-estimation of risk Around 40percent of the gross public investment funds are sent in bank stores, and the job of the banking system as a wellspring of credit is significant. Be that as it may, with the liberation of loan costs and the ascent of capital business sectors, the openness of the banks' market hazard assets have expanded. The nonappearance of satisfactory funding to ingest market hazard is showed through value unpredictability in imprint to advertise assets and accordingly can additionally highlight the issues of the banking area. The new worldwide financial emergency discovered this reason in the supported under-assessment of danger just as the decaying levels of value capital. Indian banking system, however saw to have been protected from worldwide financial emergency to an impressive degree, is at present in a significant junction, - as it needs to keep a harmony among growth and the requirement for extra capital 


\section{REFERENCES}

1. Chaudhary K., Sharma M., (2011), "Performance of Indian Public Sector Banks and Private Sector Banks: A Comparative study", International Journal of Innovation, Management and Technology, Vol. 2, No. 3,1-8, www.ijimt.org

2. DR. P.K. Srivastava, (2013), "Banking theory and practice", Himalaya Publishing House, ISBN-13: 9789350973226, 8-30

3. Gauba R., (2012), "The Indian Banking Industry: Evolution, Transformation \& the Road Ahead”, Pacific Business Review International, Volume 5 Issue 1, 85-96, www.pbr.co.in

4. Guruswamy D. (2012), "Analysis of Profitability Performance of SBI and its Associates", ZENITH International Journal of Business Economics \& Management Research, Vol.2 Issue 1, ISSN 2249 8826,1-2,20, www.zenithresearch.org.in/

5. Malviya M., (2012), "An Analysis on the Profitability, Risk and Growth Indicators of Public and Private Sector Banks", International Journal of Transformations in Business Management, ISSN: 2231-6868, Vol. No. 1, Issue No. 5, 1-12, www.ijtbm.com

6. Mishra A.K., G.S.H., Shivi A. \& Neil R.D., (2012), "Analysing Soundness in Indian Banking: A CAMEL Approach”, Research Journal of Management Sciences, ISSN 2319-1171, Vol. 1(3), 9-14, www.isca.in

7. MelakuAlemu and MelakuAweke, Financial Performance Analysis of Private Commercial Banks of Ethiopia: CAMEL Ratings. International Journal of Scientific and Research Publications, Vol.7, Issue 10, October 2017, pp.367-395

8. Pankil Solanki and Hitesh Shukla. A Comparative Study of Profitability Analysis of Selected Public and Private Sector Banks. Inspira - Journal of Commerce, Economics \& Computer Science, Vol 3, No. 03, July-Sept., 2017, pp. 136-138.

9. Ahmad Waleed, Muhammad Bilal Shah and Muhammad Kashif Mughal. Comparison of Private and Public Banks Performance. IOSR Journal of Business and Management (IOSR-JBM) e-ISSN: 2278-48X, p-ISSN: 2319-7668, Vol. 17 Issue 7. Ver: III (July 2015), pp32-38.

10. Ashish Gupta and Sundaram, V.S. Profitability Analysis of Selected Public Sector Banks in India. ZENITH International journal of Business Economics \& Management Research, Vol.5 (9), September 2015, pp. 53-62.

11. AnsarulHaque. Comparison of Financial Performance of Commercial Banks: A case study in the context of India (2009-2013). Journal of Finance and Bank Management, June 2014, Vol. 2, No.2, pp.1-14.

12. Hemal Pandya. Identifying Major Determinants of Profitability for selected Nationalized Banks in India. International Journal of Business and Administration Research Review, Vol 2, Issue .4, Jan-March, 2014, pp. 105-125.

13. ManvinderTandon, BimalAnjum and Julee. A study on Financial Performance of Selected Indian Banks. International Journal of Research in Management, Science \& Technology, Vol.2, No.3, December 2014, pp.81-92. 